\title{
Analisis Interaksi Pengguna Twitter pada Strategi Pengadaan Barang Menggunakan Social Network Analysis
}

\author{
Deinard Yordan Sihombing, Yessica Nataliani* \\ Sistem Informasi, Fakultas Teknologi Informasi, Universitas Kristen Satya Wacana \\ Jl. Diponegoro 52-60, Salatiga 50711, Indonesia \\ *e-mail: yessica.nataliani@uksw.edu
}

(received: 15 Februari 2021, revised: 12 April 2021, accepted: 17 April 2021)

\begin{abstract}
Abstrak
Meningkatnya interaksi pengguna internet dan media sosial tentu memiliki dampak terhadap peningkatan jumlah data atau konten yang dihasilkan oleh pengguna. Data atau konten yang dihasilkan sering disebut dengan User Generated Content (UGC). Data UGC dapat dimanfaatkan untuk tujuan tercapainya strategi bisnis terhadap produk yang disediakan. Hal ini dilakukan dengan menganalisis interaksi yang terjadi dengan sebuah metode yaitu Social Network Analysis (SNA), dengan membandingkan properti jaringannya. Dalam penelitian ini dilakukan analisis interaksi di dalam platform jejaring sosial yaitu Twitter pada produk smartphone Xiaomi Redmi 9, Xiaomi Redmi 9A, Xiaomi Redmi 9C, Xiaomi Redmi Note 9, dan Xiaomi Redmi Note 9 Pro. Dari perbandingan properti jaringannya dihasilkan bahwa terdapat tiga tipe smartphone yang memiliki pertimbangan untuk dilakukan perencanaan pengadaan stok ke depannya, yaitu Redmi 9A, Redmi 9C dan Redmi Note 9 Pro.
\end{abstract}

Kata kunci: Smartphone, Social Network Analysis, User Generated Content

\begin{abstract}
The increased interaction between internet and social media users will certainly have an impact on increasing the amount of data or content generated by users. The data or content generated is often referred to as User Generated Content (UGC). UGC data can be used for the purpose of achieving business strategies for the products provided. This is done by analyzing the interactions that occur, with a method, namely Social Network Analysis (SNA), by comparing the network properties. In this study, an analysis of interactions was carried out on social networking platforms, namely Twitter on the Xiaomi Redmi 9, Xiaomi Redmi 9A, Xiaomi Redmi 9C, Xiaomi Redmi Note 9, and Xiaomi Redmi Note 9 Pro. From the comparison of network properties, it can be concluded that there are three types of smartphones that have considerations for future stock procurement planning, namely Redmi 9A, Redmi 9 C and Redmi Note 9 Pro.
\end{abstract}

Keywords: Smartphone, Social Network Analysis, User Generated Content

\section{Pendahuluan}

Persaingan bisnis tidak hanya berdasarkan branding oleh organisasi atau perusahaan itu sendiri, namun tidak lepas dari strategi bisnis dalam menghadapi perusahaan kompetitor lainnya agar dapat bertahan. Salah satunya adalah dengan mengetahui daya beli pelanggan terhadap produk yang dimiliki oleh perusahaan tersebut. Sebaik apapun proses bisnis yang dilakukan, tetap bergantung pada minat beli customer atau pelanggan [1], dimana produk masih atau akan terus diminati dan apakah penyediaan produk sudah tepat sesuai dengan permintaan pasar.

Salah satu tujuan dari strategi bisnis perusahaan terletak pada ketersediaan produk untuk dijual kepada pelanggan. Untuk itu perlu adanya perencanaan yang cukup matang terhadap produk yang akan disediakan. Perencanaan pengadaan produk yang tepat akan membuat strategi bisnis lebih efisien dan efektif dalam bersaing dengan perusahaan lain, dimana jumlah permintaan yang terpenuhi akan mendorong brand dari perusahaan itu sendiri, sekaligus menunjang perkembangan bisnis. Masih banyak masalah yang terjadi hanya dikarenakan hal kecil seperti stok barang yang melebihi permintaan pasar atau stok barang habis ketika masih diminati atau masih memiliki daya jual [2]. Hal 
ini berdampak pada performa bisnis yang dijalankan oleh perusahaan sehingga dapat mempengaruhi peluang untuk bertahan dan berkembang.

Perkembangan teknologi informasi semakin cepat diterima oleh semua lapisan masyarakat mulai dari yang muda sampai lanjut usia, terutama media sosial. Media sosial semakin menjadi bagian penting dari kehidupan sehari-hari masyarakat. Selain digunakan untuk media hiburan, media sosial juga digunakan untuk saling berinteraksi, seperti komunikasi antar individu maupun kelompok, berdiskusi mengenai suatu informasi, dan banyak hal lainnya [3]. Dengan banyaknya pilihan platform media sosial untuk berinteraksi dan informasi yang diperoleh secara cepat, membuat kehidupan sosial masyarakat berpusat pada media sosial. Interaksi antara individu dalam media sosial selain terbuka untuk publik, juga menghasilkan informasi yang sangat berguna, baik untuk bidang strategi bisnis, kenegaraaan, pendidikan, kesehatan, dan lainnya.

Salah satu manfaat dari semakin banyaknya pengguna media sosial adalah dapat melihat antusias masyarakat akan sebuah informasi. Hal ini juga berlaku terhadap sebuah produk barang maupun jasa. Sebagai contoh dalam menilai tren pasar terhadap sebuah produk, yaitu dengan melihat dan menilai interaksi pengguna sosial media terhadap sebuah produk. Dikarenakan jumlah pengguna internet, khususnya pada pada platform media sosial seperti Twitter semakin meningkat [4], maka data yang dihasilkan dari platform Twitter sangat berguna jika digunakan dalam melakukan analisis pasar. Ditinjau dari hasil survei yang dilakukan oleh Asosiasi Penyelenggara Jasa Internet Indonesia (APJII) periode 2019-kuartal II/2020, jumlah pengguna internet di Indonesia mencapai 196,7 juta jiwa. Jumlah ini meningkat 23,5 juta atau 8,9\% dibandingkan pada tahun 2018 [5]. Data yang tercatat pada laporan finansial Twitter kuartal ke-3 tahun 2019 menunjukkan bahwa pengguna aktif harian di platform Twitter meningkat $17 \%$ ke angka 145 juta pengguna [6].

Dengan memanfaatkan fenomena yang terjadi, maka data dan informasi yang diperoleh dari interaksi pengguna media sosial akan sangat bermanfaat untuk penilaian tren sebuah produk atau jasa. Selain itu juga dapat dimanfaatkan untuk merencanakan penggunaan media sosial Twitter dalam pemilihan produk maupun jasa yang lebih spesifik dan kemudian dipublikasikan dengan menetapkan sasaran konsumen [7]. Hal ini dapat membantu dalam pengambilan keputusan untuk strategi bisnis perusahaan. Dengan pemanfaatan informasi ini, sebuah perusahaan dapat berkembang dan bersaing dengan kompetitor lainnya [8].

Dalam penelitian ini digunakan metode Social Network Analysis (SNA) untuk menganalisis daya jual produk yang didapat melalui ketertarikan pengguna jejaring sosial terhadap sebuah produk dan interaksi yang dilakukan antar sesama pengguna platform media sosial. Interaksi yang digunakan dalam penelitian ini adalah interaksi di antara pengguna layanan sosial media Twitter terhadap sebuah produk. Hasil dari penerapan metode ini dapat menjadi pertimbangan dalam pengembangan strategi perusahaan untuk pengadaan produk sehingga dapat lebih efektif dan efisien.

\section{Tinjauan Literatur}

Strategi pemasaran adalah sebuah cara yang dilakukan untuk memenangkan persaingan yang berkesinambungan baik untuk perusahaan yang memproduksi barang maupun jasa [9]. Berdasarkan dari banyaknya permasalahan yang terdapat di dalam sebuah perusahaan, sangat diperlukan adanya perencanaan yang matang untuk dijadikan pedoman dalam proses bisnisnya maupun untuk persaingan bisnis.

Sebagaimana penelitian yang dilakukan oleh V. Aini dan A. Almasyah, penggunaan property of network dilakukan pada penentuan peringkat brand [10]. Penelitian ini menggunakan metode SNA dengan membandingkan property of network-nya. Network atau jaringan memiliki beberapa atribut yang dapat dihitung dan kemudian dianalisis, yang dapat digunakan untuk menentukan nilai dari sebuah jaringan dalam metode SNA. Atribut tersebut disebut dengan property of network.

Mengacu pada penelitian terdahulu oleh Olmedilla, dkk., data User Generated Content (UGC) memiliki peranan penting sebagai sumber informasi bagi organisasi untuk melakukan penggalian nilai [11]. Pengambilan data UGC dilakukan dengan metode crawling data. Selanjutnya, data yang sudah dilakukan proses crawling akan di-preprocessing. Setelah normalisasi data, dilanjutkan dengan membagi data menjadi data tabel nodes dan edges.

Data UGC adalah data atau informasi yang diberikan oleh pengguna atau pelanggan terhadap sebuah brand atau produk, yang dapat berupa artikel, testimoni, review, tweets, foto, maupun video 
[12]. Data yang terdapat pada platform Twitter disebut dengan UGC, UGC pada dasarnya berasal dari orang yang secara sukarela menyumbangkan data, informasi, atau media yang kemudian oleh orang lain digunakan menjadi sesuatu yang bermanfaat atau menghibur. Selain itu dapat dikatakan bahwa UGC adalah sebuah kegiatan pengumpulan data yang diikuti dengan pengeditan, anotasi, dan visualisasi atau presentasi [13].

Berdasarkan penelitian terdahulu di atas, pada penelitian ini data UGC yang dibutuhkan untuk dianalisis menggunakan SNA adalah data berupa tweets dan retweets dari pengguna Twitter terkait sebuah produk. Data tersebut nantinya dilakukan proses preprocessing data untuk menyaring data yang dibutuhkan, dengan kata lain untuk menyaring nodes dan edges-nya. Selanjutnya, hasil preprocessing data digunakan untuk melakukan analisis produk dengan membandingkan property of network-nya.

\section{Metode Penelitian}

\subsection{Pengumpulan Data}

Penelitian ini menggunakan data yang diperoleh dari postingan user di Twitter, dimana data yang diambil merupakan postingan dan interaksi user di Twitter (seperti tweets, retweets, replies, dan sebagainya) terhadap jenis smartphone yang dijadikan sampel. Adapun jenis smartphone yang dijadikan sampel adalah Xiaomi Redmi 9, Xiaomi Redmi 9A, Xiaomi Redmi 9C, Xiaomi Redmi Note 9, dan Xiaomi Redmi Note 9 Pro. Data yang digunakan merupakan data yang diambil pada tanggal 19-27 Januari 2021, dengan jumlah data tweets sebanyak 1913 data untuk Xiaomi Redmi 9, 798 data untuk Xiaomi Redmi 9A, 392 data untuk Xiaomi Redmi 9C, 1954 data untuk Xiaomi Redmi Note 9, dan 1873 data untuk Xiaomi Redmi Note 9 Pro. Tabel 1 menunjukkan beberapa hasil crawling data dengan kata kunci 'redmi 9".

Tabel 1. Hasil Crawling Data Twitter

\begin{tabular}{|c|c|c|c|c|c|c|}
\hline $\begin{array}{l}\text { Screen } \\
\text { Name }\end{array}$ & Tweet Text & App & Followers & Follows & Listed & $\begin{array}{l}\text { User } \\
\text { Since } \\
\end{array}$ \\
\hline @ rakachannelbali & $\begin{array}{l}\text { Tutorial 2 Cara } \\
\text { Menampilkan File } \\
\text { Berkas Tersembunyi di } \\
\text { HP Xiaomi Redmi 9 } \\
\text { MIUI 12 \#comedylab } \\
\text { \#XiaomiRedmi9A } \\
\text { \#XiaomiRedmi9C } \\
\text { \#XiaomiRedmiNote9 } \\
\text { \#XiaomiRedmiNote9Pro } \\
\text { \#XiaomiPocoM2Pro } \\
\text { \#XiaomiRedmiNote8 } \\
\text { \#XiaomiRedmiNote8Pro } \\
\text { \#XiaomiRedmi9Prime } \\
\text { \#XiaomiRedmi9i } \\
\text { \#Am... }\end{array}$ & IFTTT & 280 & 872 & 0 & $\begin{array}{l}23- \\
04- \\
10\end{array}$ \\
\hline$@$ pradnyathamitha & $\begin{array}{l}\text { ini kenapa ya mau } \\
\text { setting gps di redmi } 9 \\
\text { malah gak nemu,ngecek } \\
\text { di additional setting } \\
\text { sesuai kata google } \\
\text { malah gak nemu bagian } \\
\text { privacy sama } \\
\text { locationnya } 0 \text {-尺) }\end{array}$ & $\begin{array}{l}\text { Twitter } \\
\text { for } \\
\text { iPhone }\end{array}$ & 555 & 521 & 8 & $\begin{array}{l}21- \\
06- \\
09\end{array}$ \\
\hline @Fajarnur94_new & $\begin{array}{l}\text { @ syllagin Poco M3, } \\
\text { Redmi } 9\end{array}$ & $\begin{array}{l}\text { Twitter } \\
\text { for } \\
\text { Android }\end{array}$ & 107 & 2546 & 0 & $\begin{array}{l}11- \\
10- \\
20\end{array}$ \\
\hline
\end{tabular}




\begin{tabular}{|c|c|c|c|c|c|c|}
\hline $\begin{array}{l}\text { Screen } \\
\text { Name }\end{array}$ & Tweet Text & App & Followers & Follows & Listed & $\begin{array}{l}\text { User } \\
\text { Since }\end{array}$ \\
\hline @ superluckyboi & $\begin{array}{l}\text { @ syllagin Samsung } \\
\text { a02s Redmi } 9\end{array}$ & $\begin{array}{l}\text { Twitter } \\
\text { for } \\
\text { Android }\end{array}$ & 381 & 1258 & 1 & $\begin{array}{l}22- \\
12- \\
20\end{array}$ \\
\hline @ilhmsfr & $\begin{array}{l}@ \text { Sendeva } \\
@ \text { XiaomiIndonesia } \\
\text { Udah dipake } 3 \text { bulan } \\
\text { redmi } 9 \text { yg sejak beli } \\
\text { restart2 sendiri dan } \\
\text { kadang restart ke } \\
\text { recovery mode, katanya } \\
\text { bug sw tapi udah update } \\
\text { sama aja tetap restart2 } \\
\text { sendiri, cari solusi di } \\
\text { grup kudu di factory } \\
\text { reset tp tetep sama aja, } \\
\text { alhasil dibawa ke sc } 0 \text {. } \\
\text { Ada yg bilang ic lemah } \\
\& \text { gacha si }\end{array}$ & $\begin{array}{l}\text { Twitter } \\
\text { for } \\
\text { Android }\end{array}$ & 384 & 1501 & 1 & $\begin{array}{l}14- \\
10- \\
12\end{array}$ \\
\hline @ Raditya12464220 & $\begin{array}{l}\text { @ Askrlfess Stay aja sih } \\
\text { di redmi } 9 \text {, satu emang } \\
\text { kameranya masih } \\
\text { kurang banget dibanding } \\
\text { si redmi, kedua } \\
\text { performa untuk } \\
\text { ngegame juga masih } \\
\text { kenceng mediateknya }\end{array}$ & $\begin{array}{l}\text { Twitter } \\
\text { Web } \\
\text { App }\end{array}$ & 3 & 96 & 0 & $\begin{array}{l}11- \\
11- \\
19\end{array}$ \\
\hline @ Askrlfess & $\begin{array}{l}\text { [askrl] menurut kalian } \\
\text { lebih baik upgrade poco } \\
\text { m3 atau tetap stay di } \\
\text { redmi 9? Soalnya redmi } \\
9 \text { mediatek tapi poco m3 } \\
\text { kameranya rada kurang } \\
\text { gitu ga sih?? Makasih } \\
\text { sarannya }\end{array}$ & Askrlfess & 99514 & 9219 & 1427 & $\begin{array}{l}21- \\
11- \\
19\end{array}$ \\
\hline @id_catur & $\begin{array}{l}\text { disclaimer: itu hape } \\
\text { redmi } 9 \text {, ram } 4 \mathrm{gb}, \\
\text { memory } 64 \mathrm{gb} \text {, latest } \\
\text { miui global } 12.0 .1, \\
\text { chrome ver } \\
\text { 88.0.4324.93, minat cek } \\
\text { toko sebelah }\end{array}$ & $\begin{array}{l}\text { Twitter } \\
\text { for } \\
\text { Android }\end{array}$ & 141 & 223 & 3 & $\begin{array}{c}24- \\
08- \\
11\end{array}$ \\
\hline @RickyTamara6 & $\begin{array}{l}\text { Sheet } 1 \text { !A } 899 \text { Mohon di } \\
\text { fix miui } 12 \text { pada hp } \\
\text { xiaomi dong soalnya } \\
\text { v12.1 pada redmi } 9 \\
\text { banyak bugnya }(-2)(-2)\end{array}$ & $\begin{array}{l}\text { Twitter } \\
\text { Web } \\
\text { App }\end{array}$ & 2 & 8 & 0 & $\begin{array}{l}07- \\
07- \\
20\end{array}$ \\
\hline @ madamwijaya29 & $\begin{array}{l}\text { RT @XiaomiIndonesia: } \\
\text { Kamera 8MP sudut } \\
\text { ultra-lebar dari \#Redmi9 } \\
\text { bisa diaplikasikan juga } \\
\text { untuk mendapatkan } \\
\text { lebih banyak detail di }\end{array}$ & $\begin{array}{l}\text { Twitter } \\
\text { for } \\
\text { Android }\end{array}$ & 40 & 193 & 1 & $\begin{array}{l}29- \\
03- \\
20\end{array}$ \\
\hline
\end{tabular}




\begin{tabular}{|c|c|c|c|c|c|c|}
\hline $\begin{array}{l}\text { Screen } \\
\text { Name } \\
\end{array}$ & Tweet Text & App & Followers & Follows & Listed & $\begin{array}{l}\text { User } \\
\text { Since }\end{array}$ \\
\hline @RedmiIndonesia & $\begin{array}{l}\text { tempat yang sempit. } \\
\text { Coba bandingkan } \\
\text { dengan kamera } \\
\text { biasanya. Dihargai } \\
\text { mulai dari Rp. 1.749.000 } \\
\text { (3GB+32GB), Redmi } 9 \\
\text { bisa dibeli di } \\
\text { \#GengJawara } \\
\text { Kamera 8MP sudut } \\
\text { ultra-lebar dari \#Redmi9 } \\
\text { bisa diaplikasikan juga } \\
\text { untuk mendapatkan } \\
\text { lebih banyak detail di } \\
\text { tempat yang sempit. } \\
\text { Coba bandingkan } \\
\text { dengan kamera } \\
\text { biasanya. Dihargai } \\
\text { mulai dari Rp. 1.749.000 } \\
\text { (3GB+32GB), Redmi } 9 \\
\text { bisa dibeli di } \\
\text { \#GengJawara }\end{array}$ & $\begin{array}{l}\text { Twitter } \\
\text { Web } \\
\text { App }\end{array}$ & 54592 & 54 & 38 & $\begin{array}{c}08- \\
07- \\
15\end{array}$ \\
\hline
\end{tabular}

Pengambilan data UGC dilakukan dengan metode crawling data menggunakan R Studio dengan kata kunci "redmi 9", "redmi 9A", "redmi 9c", "redmi note 9", dan "redmi note 9 pro". Data yang sudah dilakukan proses crawling selanjutnya di-preprocessing, seperti membersihkan redudansi data dan mengeliminasi akun yang diduga palsu atau tidak aktif dengan syarat mempunyai followers di atas 50. Setelah normalisasi data, dilanjutkan dengan membagi data menjadi data tabel nodes dan edges. Tabel 2 dan Tabel 3 menunjukkan salah satu hasil nodes dan edges dari preprocessing data.

\section{Tabel 2. Data Nodes}

\begin{tabular}{l}
\hline Label \\
\hline Typingmu_ \\
apondi_KE \\
_Degrata \\
chollos4iu \\
cholloschina \\
cholloschina \\
mrsvaliantkut \\
sos_kibe_ \\
_its_actuallyme \\
Kidolekumi \\
\hline
\end{tabular}


Tabel 3. Data Edges

\begin{tabular}{ll}
\hline Source & Target \\
\hline herrysw & NA \\
91mobiles & NA \\
psomnard & flrn_rss \\
psomnard & XiaomiFrance \\
psomnard & SonyFrance \\
roberbad2004 & Tsundere_Tikor \\
roberbad2004 & Apple \\
gizchinagr & NA \\
gizchinagr & NA \\
gizchinagr & NA \\
\hline
\end{tabular}

\subsection{Metode}

Metode yang digunakan dalam penelitian ini adalah metode SNA. SNA dapat menggambarkan hubungan dalam teori jaringan (network) yang terdiri dari nodes dan edges, dimana nodes adalah aktor/individu dalam suatu network dan edges adalah hubungan antar aktor. Menurut Krebs, SNA merupakan proses pemetaan dan pengukuran relasi antara orang ke orang, sedangkan Freeman berpendapat bahwa SNA sebagai teknik yang fokus mempelajari pola interaksi pada manusia yang tidak terlihat secara eksplisit. Adapun Scott mendefinisikan SNA sebagai sekumpulan metode untuk menginvestigasi aspek relasi pada struktur sosial. Dari ketiganya, secara garis besar dapat dikatakan bahwa proses SNA berkaitan dengan bentuk struktur dan pola interaksi entitas di dalamnya. SNA dapat digambarkan sebagai sebuah studi yang mempelajari tentang hubungan manusia dengan memanfaatkan teori graf [14].

Pada metode SNA, individu sebagai nodes atau titik, sedangkan relasi yang terjadi antar individu disebut dengan edges atau links. Pada dasarnya sebuah jaringan sosial bisa dikatakan sebagai sebuah peta yang terdiri atas banyak orang dimana di dalamnya terdapat relasi antar individunya [15]. Network atau jaringan memiliki atribut yang dapat dihitung dan dianalisis, yang dimana dapat digunakan untuk menentukan nilai dari sebuah jaringan dalam menggunakan metode SNA. Atribut tersebut disebut dengan properti jaringan (property of network). Tabel 4 menunjukkan properti jaringan yang digunakan.

\section{Tabel 4. Properti Jaringan}

\begin{tabular}{ll}
\hline \multicolumn{1}{c}{ Properti Jaringan } & Fungsi \\
\hline Size & Jumlah nodes dan edges dalam sebuah jaringan. \\
Density & $\begin{array}{l}\text { Tingkat hubungan antar nodes dalam sebuah jaringan. Semakin tinggi } \\
\text { nilai density, maka semakin tinggi hubungan yang dimiliki. }\end{array}$ \\
Modularity & Banyaknya kelompok yang dimiliki oleh jaringan tersebut. \\
Diameter & Jarak terjauh antara dua nodes yang berdekatan. \\
Average Degree & Rata-rata jumlah edges yang menghubungkan tiap nodes. \\
Average Path Length & Rata-rata jalur yang dilewati oleh tiap nodes ke nodes yang lain. \\
Clustering Coefficient & Gambaran hubungan suatu nodes dengan nodes di sekitarnya. \\
Connected Component & Banyaknya komponen yang terhubung dalam suatu jaringan. \\
\hline
\end{tabular}

Dalam memodelkan data jaringan sosial digunakan metode SNA untuk menghasilkan graf dan properti jaringan yang dibutuhkan untuk menganalisis produk yang dijadikan sampel. Dari model jaringan sosial yang telah diperoleh dapat dilihat properti jaringan sosial untuk kemudian dianalisis. Hasil dari analisis yang dilakukan dapat dijadikan acuan dalam mengambil keputusan apakah produk yang diunggulkan masih diminati, sekaligus mempelajari pola interaksi user terhadap produk smartphone yang dimiliki. Adapun tahapan dalam penelitian ini dapat dilihat pada Gambar 1. 


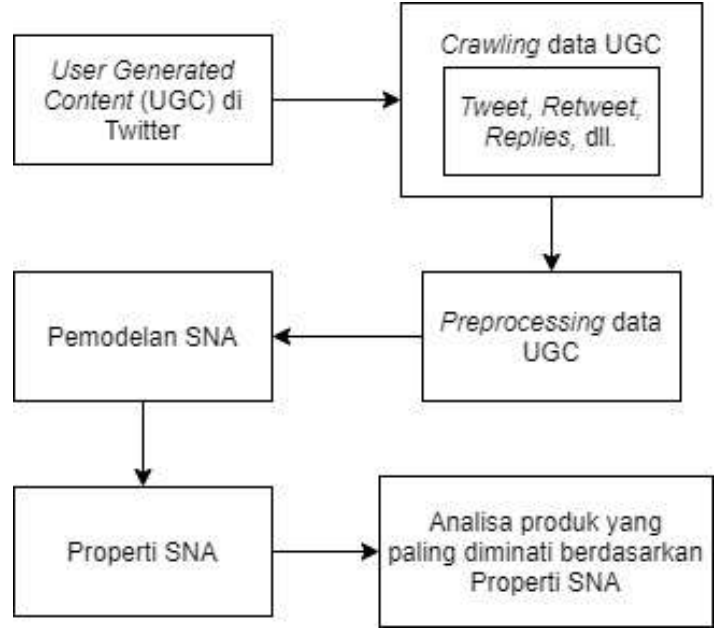

Gambar 1. Tahapan Penelitian

\section{Hasil dan Pembahasan}

\subsection{Hasil}

Setelah melakukan pemodelan jaringan sosial pada data UGC yang telah di-preprocessing menggunakan metode SNA terhadap kelima smartphone yang dijadikan sampel, didapatkan hasil visualisasi dalam bentuk graf. Untuk pemodelan graf jaringan sosial digunakan software Gephi dengan layout ForceAtlas2. Hasil visualisasi ini merupakan pemodelan jaringan sosial pengguna Twitter (nodes) terhadap produk smartphone yang dijadikan sampel dengan kata kunci "redmi 9", "redmi 9A", "redmi 9c", "redmi note 9", dan "redmi note 9 pro". Bentuk graf dapat dilihat pada Gambar 2.

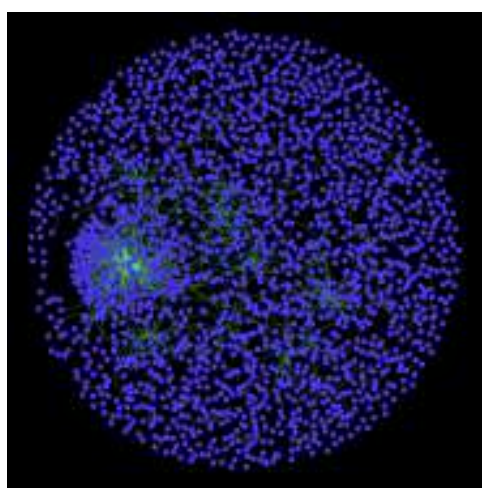

(a) Xiaomi Redmi 9

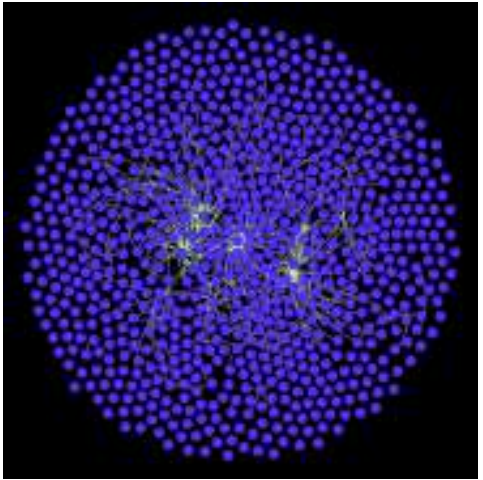

(b) Xiaomi Redmi 9A

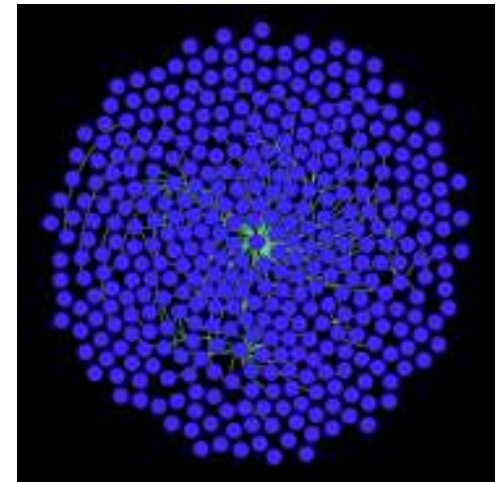

(c) Xiaomi Redmi 9C

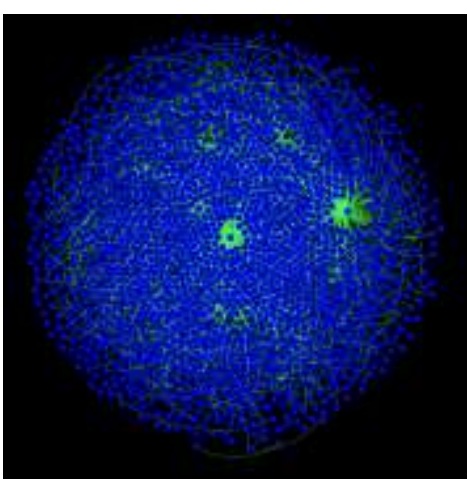

(d) Xiaomi Redmi Note 9 Pro

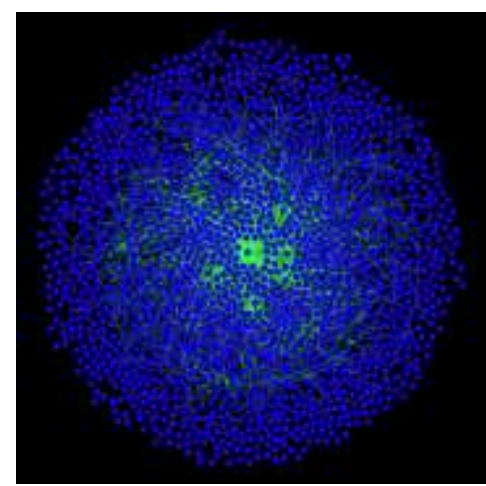

(e) Xiaomi Redmi Note 9

Gambar 2. Visualisasi Jaringan: (a) Xiaomi Redmi 9, (b) Xiaomi Redmi 9A, (c) Xiaomi Redmi 9C, (d) Xiaomi Redmi Note 9 Pro, (e) Xiaomi Redmi Note 9 
Dari hasil visualisasi jaringan, selanjutnya dilakukan perhitungan nilai metrik pada properti jaringan menggunakan software Gephi. Dari perhitungan tersebut didapatkan hasil properti jaringan dari kelima produk smartphone yang dapat dilihat pada Tabel 5.

Tabel 5. Perhitungan dan Perbandingan Properti Jaringan

\begin{tabular}{|c|c|c|c|c|c|c|c|}
\hline No & $\begin{array}{l}\text { Properti } \\
\text { Jaringan }\end{array}$ & Redmi 9 & $\begin{array}{l}\text { Redmi } \\
\text { 9A }\end{array}$ & $\begin{array}{l}\text { Redmi } \\
\text { 9C }\end{array}$ & $\begin{array}{l}\text { Redmi } \\
\text { Note } 9\end{array}$ & $\begin{array}{l}\text { Redmi } \\
\text { Note } 9 \\
\text { Pro } \\
\end{array}$ & Peringkat \\
\hline 1 & Size & $\begin{array}{l}\text { Nodes: } \\
1913 \\
\text { Edges: } \\
822\end{array}$ & $\begin{array}{l}\text { Nodes: } \\
798 \\
\text { Edges: } \\
304\end{array}$ & $\begin{array}{l}\text { Nodes: } \\
392 \\
\text { Edges: } \\
157\end{array}$ & $\begin{array}{l}\text { Nodes: } \\
\text { 1954 } \\
\text { Edges: } \\
863\end{array}$ & $\begin{array}{l}\text { Nodes: } \\
1873 \\
\text { Edges: } \\
859\end{array}$ & $\begin{array}{l}\text { 1. Redmi Note } 9 \\
\text { 2. Redmi } 9 \\
\text { 3. Redmi Note } 9 \\
\text { Pro } \\
\text { 4. Redmi 9A } \\
\text { 5. Redmi 9C }\end{array}$ \\
\hline 2 & Density & 0.000 & 0.001 & 0.002 & 0.000 & 0.000 & $\begin{array}{l}\text { 1. Redmi 9C } \\
\text { 2. Redmi 9A } \\
\text { 3. Redmi } 9 \\
\text { 4. Redmi Note } 9 \\
\text { 5. Redmi Note } 9 \\
\text { Pro }\end{array}$ \\
\hline 3 & Modularity & 0.836 & 0.709 & 0.732 & 0.830 & 0.797 & $\begin{array}{l}\text { 1. Redmi 9A } \\
\text { 2. Redmi 9C } \\
\text { 3. Redmi Note } 9 \\
\text { Pro } \\
\text { 4. Redmi Note } 9 \\
\text { 5. Redmi } 9\end{array}$ \\
\hline 4 & Diameter & 8 & 4 & 4 & 7 & 11 & $\begin{array}{l}\text { 1. Redmi 9A } \\
\text { 2. Redmi 9C } \\
\text { 3. Redmi Note } 9 \\
\text { 4. Redmi } 9 \\
\text { 5. Redmi Note } 9 \\
\text { Pro }\end{array}$ \\
\hline 5 & $\begin{array}{l}\text { Average } \\
\text { Degree }\end{array}$ & 0.859 & 0.762 & 0.801 & 0.883 & 0.917 & $\begin{array}{l}\text { 1. Redmi Note } 9 \\
\text { Pro } \\
\text { 2. Redmi Note } 9 \\
\text { 3. Redmi } 9 \\
\text { 4. Redmi 9C } \\
\text { 5. Redmi 9A }\end{array}$ \\
\hline 6 & $\begin{array}{l}\text { Average } \\
\text { Path } \\
\text { Length }\end{array}$ & 2.964 & 2.273 & 2.45 & 2.572 & 2.978 & $\begin{array}{l}\text { 1. Redmi 9A } \\
\text { 2. Redmi 9C } \\
\text { 3. Redmi Note } 9 \\
\text { 4. Redmi } 9 \\
\text { 5. Redmi Note } 9 \\
\text { Pro }\end{array}$ \\
\hline 7 & $\begin{array}{l}\text { Clustering } \\
\text { Coefficient }\end{array}$ & 0.00142 & 0.00212 & 0.00001 & 0.00172 & 0.00327 & $\begin{array}{l}\text { 1. Redmi Note } 9 \\
\text { Pro } \\
\text { 2. Redmi 9A } \\
\text { 3. Redmi Note } 9 \\
\text { 4. Redmi } 9 \\
\text { 5. Redmi 9C }\end{array}$ \\
\hline 8 & $\begin{array}{l}\text { Connected } \\
\text { Component }\end{array}$ & 1114 & 529 & 235 & 1117 & 1071 & $\begin{array}{l}\text { 1. Redmi 9C } \\
\text { 2. Redmi 9A } \\
\text { 3. Redmi Note } 9 \\
\text { Pro }\end{array}$ \\
\hline
\end{tabular}




\begin{tabular}{clllllll}
\hline No & $\begin{array}{l}\text { Properti } \\
\text { Jaringan }\end{array}$ & Redmi 9 & $\begin{array}{l}\text { Redmi } \\
\text { 9A }\end{array}$ & $\begin{array}{l}\text { Redmi } \\
\text { 9C }\end{array}$ & $\begin{array}{l}\text { Redmi } \\
\text { Note 9 }\end{array}$ & $\begin{array}{l}\text { Redmi } \\
\text { Note 9 } \\
\text { Pro }\end{array}$ & Peringkat \\
\hline & & & & $\begin{array}{l}\text { 4. Redmi 9 } \\
\text { 5. Redmi Note 9 }\end{array}$ \\
\hline
\end{tabular}

Tabel 2 menjelaskan hasil perhitungan dan perbandingan peringkat pada properti jaringan smartphone. Untuk properti pertama yaitu size, dimana size terbesar adalah smartphone dengan tipe Redmi Note 9 dengan jumlah 1954 nodes dan 863 edges, kemudian diikuti Redmi 9 dengan jumlah 1913 nodes dan 822 edges, Redmi Note 9 Pro dengan jumlah 1873 nodes dan 859 edges, Redmi 9A dengan jumlah 798 nodes dan 304 edges, serta terakhir Redmi 9C dengan jumlah 392 nodes dan 157 edges.

Properti kedua adalah density. Semakin besar nilai density yang didapat maka semakin padat jaringan yang dimiliki. Berdasarkan density, maka peringkat pertama diduduki oleh Redmi 9C, kemudian Redmi 9A di peringkat kedua, diikuti Redmi 9, Redmi Note 9, Redmi 9 dengan perolehan density yang sama.

Properti selanjutnya adalah modularity yang mengukur kelompok-kelompok pada jaringan. Setiap kelompok yang terbentuk diasumsikan sebagai komunitas yang berbeda. Dengan meningkatnya komunitas dalam sebuah jaringan, penyebaran informasi mengenai produk semakin spesifik dan luas. Jaringan yang memiliki nilai modularity diurutkan dari yang paling baik adalah Redmi 9A, Redmi 9C, Redmi Note 9 Pro, Redmi Note 9, dan terakhir Redmi 9.

Properti jaringan selanjutnya adalah diameter. Semakin kecil diameter yang dimiliki sebuah jaringan, berarti semakin pendek jarak antara dua nodes yang saling berjauhan. Peringkat smartphone berdasarkan diameter-nya adalah Redmi 9A pada posisi pertama dengan nilai 4, kemudian Redmi 9C pada posisi kedua dengan nilai 4, Redmi Note 9 pada posisi ketiga dengan nilai 7, Redmi 9 pada posisi keempat dengan nilai 8, dan pada posisi kelima adalah Redmi Note 9 Pro dengan nilai 11.

Properti selanjutnya adalah Average Degree, dimana ini merupakan jumlah link yang menghubungkan tiap node. Semakin banyak jumlah link yang dimiliki maka penyebaran informasi terkait produk semakin cepat. Peringkat smartphone berdasarkan Average Degree, pertama adalah Redmi Note 9 Pro, kemudian Redmi Note 9 pada posisi kedua, di posisi ketiga ada Redmi 9, Redmi 9C pada posisi keempat, dan terakhir Redmi 9A pada posisi kelima.

Average Path Length, yang menunjukkan jarak rata-rata tiap nodes. Semakin kecil nilai average path length, maka penyebaran informasi mengenai produk juga semakin cepat. Urutan smartphone berdasarkan average path length-nya adalah Redmi 9A, Redmi 9C, Redmi Note 9, Redmi 9, dan terakhir Redmi Note 9 Pro.

Clustering Coefficient menunjukkan hubungan antar nodes. Posisi pertama adalah Redmi Note 9 Pro, kemudian di posisi kedua adalah Redmi 9A, di posisi ketiga adalah Redmi Note 9, kemudian Redmi 9 pada posisi keempat, dan di posisi kelima adalah Redmi 9C.

Properti terakhir adalah Connected Component, yang merupakan kumpulan yang saling terpisah dari kelompok nodes yang berhubungan dalam suatu graf. Semakin besar nilainya, maka jaringan tersebut dapat membentuk banyak kelompok yang saling terhubung. Peringkat jaringan smartphone berdasarkan properti ini adalah Redmi 9C, Redmi 9A, Redmi Note 9 Pro, Redmi 9, dan Redmi Note 9.

\subsection{Pembahasan}

Dari hasil perhitungan dan analisis perbandingan berdasarkan properti jaringan Size, Density, Modularity, Diameter, Average Degree, Average Path Length, Clustering Coefficient, dan Connected Component dihasilkan nilai untuk masing-masing jaringan. Setelah dilakukan perbandingan terhadap nilai properti jaringan tiap sampel smartphone, didapatkan hasil berupa peringkat berdasarkan metriknya. Redmi 9A unggul pada tiga properti yaitu modularity, yang menunjukkan kelompok yang terbentuk dalam jaringan sangat banyak, properti diameter, yang menunjukkan bahwa dalam jaringan ini memiliki jalur terpendek untuk tiap nodes-nya, dan properti average path length, yang menunjukkan penyebaran informasi yang cepat. 
Redmi 9C unggul pada dua properti yaitu density, yang menunjukkan bahwa jaringan ini memiliki interaksi yang lebih padat dan connected component, yang menunjukkan bahwa jaringan tersebut dapat membentuk banyak kelompok yang saling berhubungan.

Redmi Note 9 unggul pada properti size, yang menunjukkan bahwa aktor yang berperan dalam jaringannya memiliki jumlah yang banyak. Sementara itu, Redmi Note 9 Pro unggul pada dua properti, yaitu average degree, dimana jaringan ini memiliki banyak jumlah edges yang menghubungkan tiap nodes, yang menunjukkan penyebaran informasi produk dengan cepat dan properti clustering coefficient, yang menunjukkan bahwa hubungan node yang ada pada jaringan tersebut lebih kuat.

Hasil analisis menggunakan bahwa metode SNA dapat menganalisis dengan mengukur dinamika sosial pasar, penyebaran informasi, penularan informasi, dan sebagainya. Di samping itu, metode ini juga melihat penularan informasi melalui media sosial, yang sangat relevan dengan era dimana setiap orang selalu berinteraksi di berbagai platform sosial media, salah satunya adalah Twitter.

\section{Kesimpulan}

Dari hasil analisis yang didapat, terdapat tiga tipe smartphone yang memiliki pertimbangan untuk dilakukan perencanaan pengadaan stok ke depannya, yaitu Redmi 9A berada pada posisi pertama untuk menjadi rekomendasi dan kemudian Redmi 9C dan Redmi Note 9 Pro untuk menjadi alternatif. Hal yang menjadi pertimbangan perlunya ketersediaan Redmi 9A adalah karena dari hasil analisis peringkat properti jaringan yang diperoleh, interaksi pengguna terkait produk ini dilakukan oleh banyak kelompok dengan jalur berbagi informasi yang pendek dan respon yang cepat menyebar. Hal ini menandakan bahwa produk Redmi 9A sedang diminati. Begitu juga dengan Redmi 9C yang memiliki kepadatan interaksi pengguna yang tinggi dan memiliki potensi untuk dibahas oleh banyak kelompok di media sosial, sehingga produk ini dikatakan lumayan diminati. Selanjutnya, Redmi Note 9 Pro memiliki banyak interaksi individu ke individu berbeda dan penyebaran informasi mengenai produk cepat menyebar. Jadi dikatakan bahwa produk ini juga lumayan diminati dan sangat sering dibahas di media sosial.

\section{Referensi}

[1] H. Jati, W., \& Yuliansyah, "Pengaruh Strategi Pemasaran Online (Onlinearketing Strategy) Terhadap Minat Beli Konsumen," J. Pemasar. Kompetitif, vol. 125, 2017.

[2] W. M. Baihaqi, K. Indartono, and S. Banat, "Penerapan Teknik Clustering Sebagai Strategi Pemasaran pada Penjualan Buku Di Tokopedia dan Shopee," Paradig. - J. Komput. dan Inform., vol. 21, no. 2, pp. 243-248, 2019, doi: 10.31294/p.v21i2.6149.

[3] A. E. P. Harrera, "Pemanfaatan Media Sosial Twitter oleh Ridwan Kamil dan Ganjar Pranowo Telah Sesuai dengan Fungsi Utama Media Massa," J. Messenger, vol. 8, no. 2, p. 52, 2016, doi: 10.26623/themessenger.v8i2.335.

[4] M. K. B. Wildan Ignatio, Muhammad Rizqy Dwi Putra, "Penentuan Top Brand Menggunakan Social Network Analysis pada E-Commerce Bukalapak dan Tokopedia," J. Inf. Eng. Educ. Technol., vol. 02, p. 5, 2018.

[5] "Jumlah Pengguna Internet di Indonesia Capai 196,7 Juta | Databoks." https://databoks.katadata.co.id/datapublish/2020/11/11/jumlah-pengguna-internet-di-indonesiacapai-1967-juta (accessed Feb. 06, 2021).

[6] "Pengguna Aktif Harian Twitter Indonesia Diklaim Terbanyak." https://tekno.kompas.com/read/2019/10/30/16062477/pengguna-aktif-harian-twitter-indonesiadiklaim-terbanyak (accessed Feb. 06, 2021).

[7] L. Maryati, "Strategi Komunikasi Penggunaan Twitter Dalam Kegiatan Promosi Kuliner," J. Chem. Inf. Model., vol. 53, no. 9, pp. 1689-1699, 2019.

[8] J. Bollen, H. Mao, and X. Zeng, "Twitter mood predicts the stock market," J. Comput. Sci., 2011, doi: 10.1016/j.jocs.2010.12.007.

[9] D. H. Wibowo, Z. Arifin, and . Sunarti, "Analisis Strategi Pemasaran Untuk Meningkatkan Daya Saing UMKM (Studi pada Batik Diajeng Solo)," J. Adm. Bisnis, vol. 29, no. 1, pp. 5966, 2015, [Online]. Available: http://administrasibisnis.studentjournal.ub.ac.id/index.php/jab/article/view/1172. 
[10] V. N. Aini and A. Alamsyah, "Analisis pada peringkat top brand menggunakan jejaring sosial percakapan dengan social network analysis (Studi kasus pada smartphone Samsung, Blackberry, Nokia, Iphone di Indonesia )," e-Proceeding Manag., vol. 3, no. 1, pp. 77-85, 2016.

[11] M. Olmedilla, M. R. Martínez-Torres, and S. L. Toral, "Harvesting Big Data in social science: A methodological approach for collecting online user-generated content," Comput. Stand. Interfaces, vol. 46, pp. 79-87, May 2016, doi: 10.1016/j.csi.2016.02.003.

[12] "Mengapa User-Generated Content menjadi Strategi Marketing yang Efektif? - SIRCLO." https://www.sirclo.com/mengapa-user-generated-content-menjadi-strategi-marketing-yangefektif/ (accessed Apr. 13, 2021).

[13] J. Krumm, N. Davies, and C. Narayanaswami, "User-generated content," Environ. Sci. Technol., vol. 41, no. 13, p. 4487, 2007, doi: 10.1021/es0725605.

[14] M. Tsvetovat and A. Kouznetsov, Social Network Analysis for Startups. 2011.

[15] B. Susanto, H. Lina, and A. R. Chrismanto, "Penerapan Social Network Analysis dalam Penentuan Centrality Studi Kasus Social Network Twitter,” J. Inform., vol. 8, no. 1, 2012, doi: 10.21460/inf.2012.81.111. 